\title{
Preparation of Composite Microporous Glass Membrane on Ceramic Tubing*
}

\author{
Haruhiko Ohya, Yoshinori Tanaka, Masahiro Niwa, Racope Hongladaromp, \\ Yoichi Negishi and Kanji Matsumoto ${ }^{* *}$
}

Department of Material Science and Chemical Engineering, Yokohama National University, 156 Tokiwadai, Hodogaya-ku, Yokohama 240

Porous thin glass membranes of which thickness is in the range of 5 to $23 \mu \mathrm{m}$ have been prepared on the surface of porous ceramic tubing by coating with metal alkoxide solution, drying, heating and acid leaching sequentially. Structure of the membranes was investigated by Scanning Electron Microscope, and found that pore size is in the range of 4 to $64 \mathrm{~nm}$.

Key words: Membrane, Composite membrane, Porous glass, Ceramic tubing, Gas separation, Metal alkoxide coating

Microporous glass membranes have advantages of their chemical and thermal stability as well as higher permeability over organic membranes. The preparation of the microporous glass was first patented by Hood \& Nordberg ${ }^{1)}$. A mixture of glass material was used in order to make a phase separable glass that results in the separation of an acid soluble phase and this phase can be removed by acid leaching. Thus, a microporous structure is obtained as an intermediate stage in the manufacturing of Vycorbrand glass. Commercially available microporous glass membrane, however, has some disadvantages, that is, 1st, their thickness is very thick of several mms and 2nd, it seems impossible to make them into a module which has large membrane area for commercial application.

We have tried to fabricate very thin microporous glass membrane on the surface of porous ceramic tubing of small diameter

\footnotetext{
* 多孔質セラミック円管上に微多孔ガラス薄膜を形成させた複合 膜

** 大矢晴彦・田中佳典・丹羽雅裕・ R・ホングラダロム・根岸洋 一・松本幹治・横浜国立大学物質工学科 $\mathbf{T} 240$ 横浜市保 土谷区常盤台 156
}

\section{Membrane Making Procedure}

Thin layer of microporous glass was fabricated on the surface of porous ceramic tubing (supplied by TDK Co., Ltd.) using the method described by Sakka ${ }^{2)}$. The procedure is shown schematically on Fig.1. The compositions of metal alkoxide solutions which was used in the coating process onto the ceramic tubing, are listed on Table 1.

Porous ceramic tubing of which the dimensions

$$
\text { ALKOLATE METHOD }
$$

\begin{tabular}{|c|}
\hline $\begin{array}{r}\mathrm{i}\left(\mathrm{OC}_{2} \mathrm{H}_{5}\right)_{4}: \mathrm{C}_{2} \mathrm{H}_{5} \mathrm{OH}: \mathrm{H}_{2} \mathrm{O}: \mathrm{HCl}= \\
25: \quad 37.5: 23.6: 0.3 \\
+\mathrm{H}_{3} \mathrm{BO}_{3} \text { or } \mathrm{B} ? 03 \\
\end{array}$ \\
\hline$\frac{\Downarrow \text { MIXING AND STIRRING }}{\text { RTIALLY HYDROLYZED SOLU }}$ \\
\hline
\end{tabular}

PARTIALLY HYDROLYZED SOLUTION

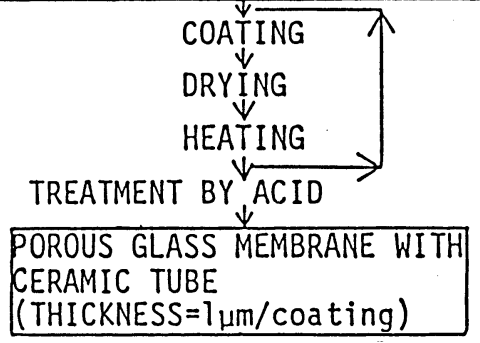

Fig. 1 Procedure of Composite Porous Glass Membrane by Alkolate Method 
42 H. Ohya, et al.: Preparation of Composite Microporous Glass Membrane on Ceramic Tubing

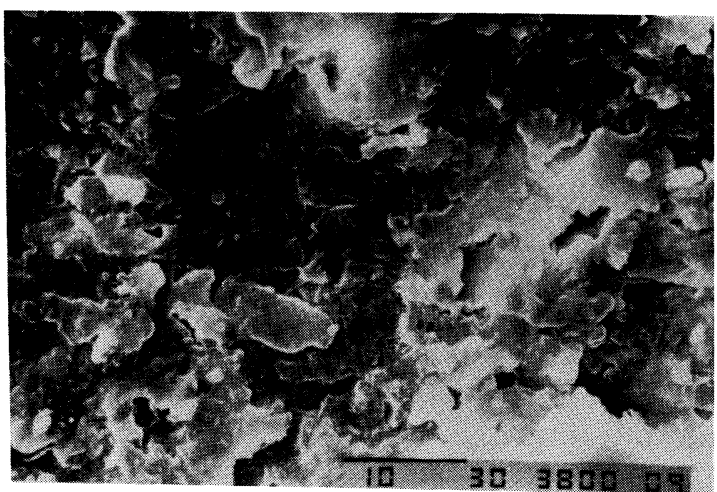

(a) Surface of Virgin Ceramic Tubing

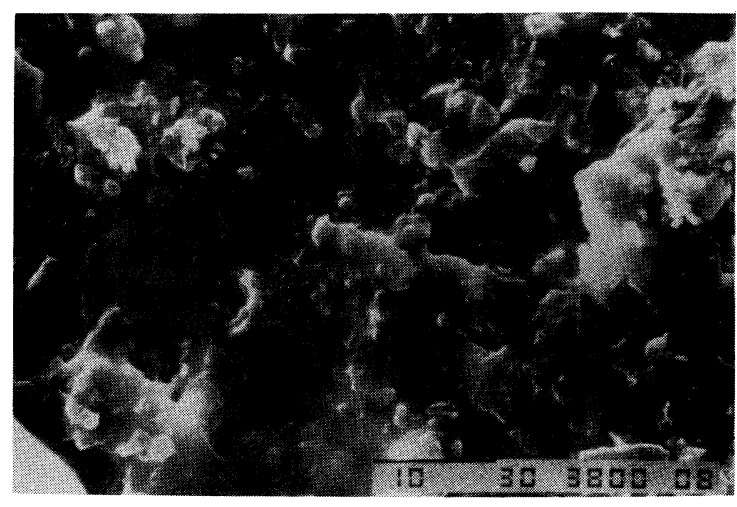

(b) Surface of Only One Time Coated

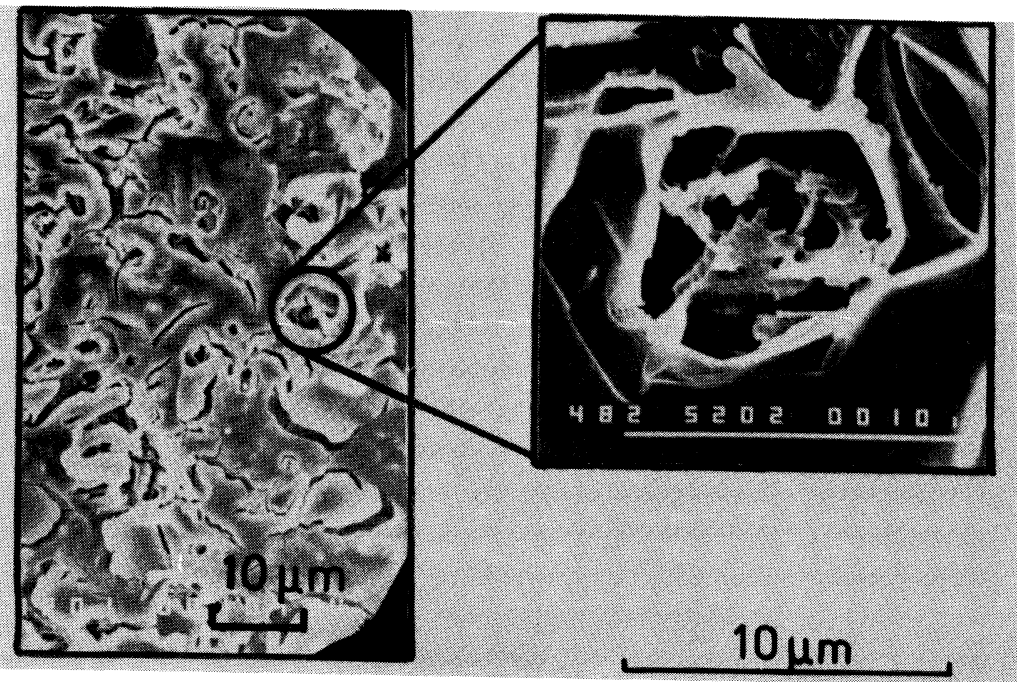

(c) Surface of 15 Times Coated and Acid Leached

(d) Enlarged Photo of Pore

Fig. 2 Sequential Change of Structure

were $2 \mathrm{~mm}$ of outer diameter and $1 \mathrm{~mm}$ of inner diameter was dipped in metal alkoxide solution from sealed end and pulled out with speed of $2 \mathrm{~mm} / \mathrm{s}$. The solution coated on ceramic tubing was dried 1 minute or so at room temperature, tnen placed in electric furnace and heated at $550^{\circ} \mathrm{C}$ for 60 minutes then taken out to cool down. After the procedure of coating, drying and heating was repeated several times, the tubing was dipped in aqueous $3 \mathrm{M}$ HCI acid solution at $80^{\circ} \mathrm{C}$ for 6 hours to leach out acid soluble phase so as to make the membrane porous. The acid leached membrane washed by pure
Table 1 Compositjons of Alkoxide Solutions for Coating

\begin{tabular}{|c|c|c|c|c|c|c|c|}
\hline embrane & $A A$ & ABI & $\mathrm{AB2}$ & $\mathrm{ACL}$ & $A C 2$ & $\mathrm{AC} 3$ & $A C 4$ \\
\hline \multirow{7}{*}{$\begin{array}{l}\mathrm{Si}\left(\mathrm{OC}_{2} \mathrm{H}_{4}\right)_{4} \\
\mathrm{C}_{2} \mathrm{H}_{5} \mathrm{OH} \\
\mathrm{H}_{2} \mathrm{O} \\
\mathrm{HCl} \\
\mathrm{H}_{3} \mathrm{BO}_{3} \\
\mathrm{~B}_{2} \mathrm{O}_{3} \\
\mathrm{SiO}_{2} \mathrm{~B}_{2} \mathrm{O}_{3} \\
\text { Coating times } \\
\text { Memb.Thickness }\end{array}$} & & & Quar & ntity & (g) & & \\
\hline & $\begin{array}{c}25 \\
37.6 \\
23.7\end{array}$ & $\begin{array}{c}25 \\
37.6 \\
23.7\end{array}$ & $\begin{array}{c}25 \\
37.6 \\
23.7\end{array}$ & $\begin{array}{c}25 \\
37.6 \\
23.7\end{array}$ & $\begin{array}{c}25 \\
37.6 \\
23.7\end{array}$ & $\begin{array}{c}25 \\
37.6 \\
23.7\end{array}$ & $\begin{array}{c}25 \\
37.6 \\
23.7\end{array}$ \\
\hline & 0.3 & 0.3 & 0.3 & 0.3 & 0.3 & 0.3 & 0.3 \\
\hline & $\begin{array}{l}0 \\
0\end{array}$ & $\begin{array}{r}0 \\
0.5\end{array}$ & $\begin{array}{r}0 \\
1.0\end{array}$ & $\begin{array}{r}3.2 \\
0\end{array}$ & $\begin{array}{r}3.2 \\
0\end{array}$ & 3.2 & .2 \\
\hline & $\overline{0}$ & 14 & $77^{2}$ & 4 & 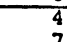 & & 4 \\
\hline & & & & & & & \\
\hline & 18 & 23 & 23 & 23 & 15 & 13 & 6 \\
\hline
\end{tabular}

water at room temperature for more than 10 hours and dried at $80-100^{\circ} \mathrm{C}$ for over night. 


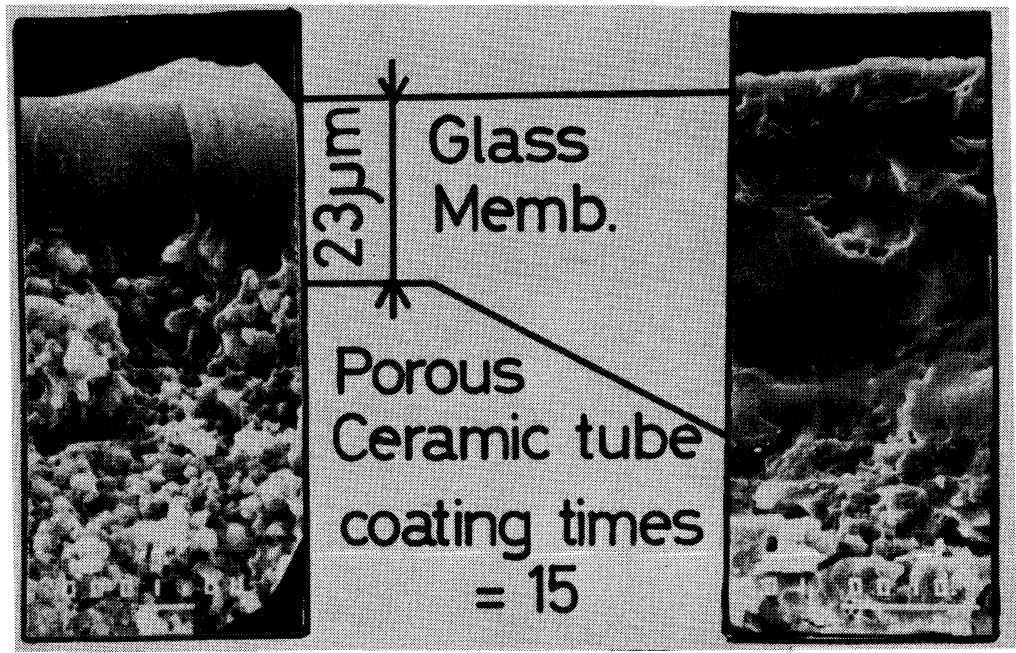

Fig. 3 Cross Sectional View of Membrane

\section{The Structure of Membrane}

Using Scanning Electron Microscope(SEM), sequential change of the appearance of the structure of glass membrane during the course of membrane making was observed. Fig.2-a shows surface of ceramic tubing before coating. Fig.2-b shows surface of only one time coated glass layer of the alkoxide before the acid treatment process. The configuration of the glass layer is rough as same as virgin ceramic tubing but small pores which can be seen on the original ceramic tubing are disappeared. Fig.2c shows surface of 15 times alkoxide coated glass membrane after acid treatment. There are pore of which sizes are in the order of several tenth $\mu \mathrm{m}$ to several $\mu \mathrm{m}$, and are becoming smaller toward the inside of the membrane as shown on Fig.2-d.

The membrane thickness, which was measured on the SEM photo of the cross sectional view shown on Fig. 3 as an example, is plotted against coating times on Fig.4. The thickness at 5 times was about $13 \mu \mathrm{m}$ and at 15 times about $23 \mu \mathrm{m}$. After the 5th times of coating, the increment of thickness is around $1 \mu \mathrm{m}$ for every coating.

\section{Mean Pore Diameter}

Permeation rate (P.R.) through porous media

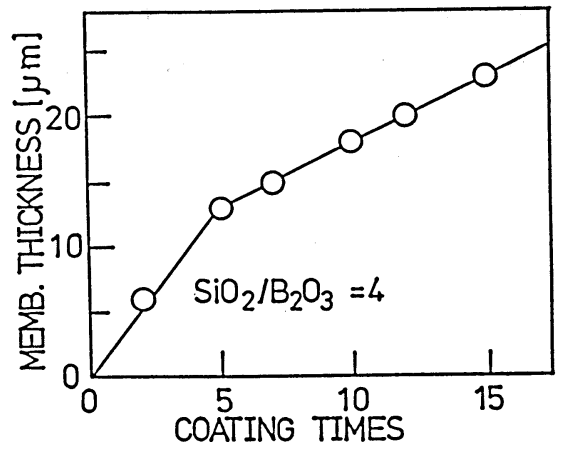

Fig. 4 Increase of Membrane Thickness with Repeat of Coating

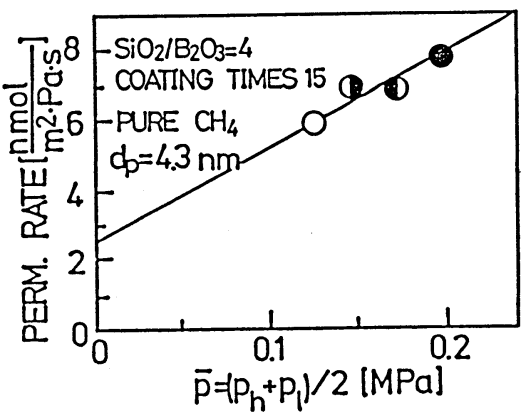

Fig. 5 Permeation Rate vs. Mean Pressure

is expressed by the Eq. 1 in which the first term represents Knudsen flow and the second viscous flow. Where $K_{0}$ is permeation rate of Knudsen flow, $\eta$ viscosity of the gas and $B_{0}$ geometric factor of membrane and $\bar{p}$ average pressure over 
44 H. Ohya, et al.: Preparation of Composite Microporous Glass Membrane on Ceramic Tubing

Table 2 Mean Pore Size of Pourous Glass Membrane

\begin{tabular}{|c|c|c|}
\hline $\begin{array}{l}\text { Coating } \\
\text { Times }\end{array}$ & $\frac{\mathrm{SiO}_{2}}{\mathrm{~B}_{2} \mathrm{O}_{3}}$ & $\begin{array}{l}\text { Mean } \\
\text { Pore } \\
\text { Size } \\
{[\mathrm{nm}]}\end{array}$ \\
\hline 2 & 4 & 64.0 \\
\hline 5 & 4 & 24.0 \\
\hline 7 & 4 & 6.8 \\
\hline 15 & 4 & 4.3 \\
\hline 15 & 7 & 8.1 \\
\hline 15 & 14 & 7.8 \\
\hline
\end{tabular}

the membrane. Mean pore diameter of the porous media $d_{p}$ is expressed by the Eq. $2^{4)}$

$$
\begin{aligned}
& P . R .=K_{\mathrm{o}}+\left(B_{\mathrm{o}} / \eta\right) \bar{p} \\
& d_{p}=\left(B_{\mathrm{o}} / K_{\mathrm{o}}\right)(16 / 3)(2 R T / \pi)^{\frac{1}{2}} \mathrm{M}^{-\frac{1}{2}}
\end{aligned}
$$

Fig.5 shows a typical example obtained with pure methane gas, and gives $d_{p}$ as $4.3 \mathrm{~nm}$. Mean pore diameters for other membranes are listed on Table 2. When coating time increases, the mean pore diameter decreases for $\left(\mathrm{SiO}_{2}: \mathrm{B}_{2} \mathrm{O}_{3}=\right.$ $4: 1)$ membrane.

\section{Acknowledgement}

This work was supported by Biomass Conversion Project from the Ministry of Agriculture and Fisheries.

\section{References}

1) H.P. Hood, M. E. Nordberg: U.S. patent 2, 106, 744 (1938)

2) K. Kamiya, Y. Sakka: J. Ceramic Japan, 86, 562, (1978)

3) H. Adzumi : Bull. Chem. Soc. Japan, 12, 285, (1937)

4) H. Yasuda: J. Appl. Polymer Sci., 18, 805, (1974) 